Biografistyka Pedagogiczna

Rok 6 (2021) nr 2

ISSN 2543-6112; e-ISSN 2543-7399

DOI:10 .36578/BP.2021.06.51

\title{
Alina Rynio*
}

\section{Pedagogiczny charyzmat Sługi Bożego Ks. Luigiego Giussaniego (1922-2005)}

\section{The Pedagogical Charism of God's Servant Fr. Luigi Giussani (1922-2005)}

\begin{abstract}
This publication presents the manifold charismatic pedagogical activity of the Italian teacher and educator, and now God's Servant, Fr. Luigi Giussani. Undoubtedly Fr. Giussani, due to his extraordinary insight and courage, was a well-known and appreciated figure not only at the university and in church, but also in school, cultural and political life.

The author of the study, taking into consideration the pedagogical aspect, draws attention to Giussani as an exceptional teacher and educator. The author not only introduces Giussani's way of understanding pedagogy and education, but also confirms his uniqueness by presenting selected accomplishments described in his biography. As a teacher and educator, Fr. Giussani distinguished himself by a sober and realistic view of people and their education. Giussani's attitude was characterized by a complete abandonment to God and great love for every person he met, emphasizing the value of an individual as an intelligent and free being.

The publication contains a short biographical sketch. Furthermore, it describes Fr. Giussani's preferred methods of education, educative events, elements constituting the personality of the educator and the educated person. It also shows the connection between education and freedom, conscience as well as tradition.
\end{abstract}

Keywords: Fr. Luigi Giussani, biographical sketch, education, educative events, elements constituting the personality of the educator and the educated person, the connection between education and freedom, conscience as well as tradition.

* Alina Rynio (ORCID: 00oo-0oo3-4113-7620) - dr hab., pracuje w Instytucie Pedagogiki (Katedra Pedagogiki Chrześcijańskiej i Biografistyki Pedagogicznej na Katolickim Uniwersytecie Lubelskim Jana Pawła II, kontakt: alina.rynio@kul.pl. 
Dóżne z pewnością były nędze i niedostatki, z którymi spotykali się uczeni, 1 nauczający i uczący się, i z powodu których cierpieli w starożytności, średniowieczu, odrodzeniu czy minionym stuleciu. Różne są i dziś wyzwania, przed którymi życie stawia każdego z nas. Patrząc na rozwiązania czasów dawnych, trzeba przyznać, że wiele z nich nosi znamię niezwykłej mądrości i prostoty, której wydaje się brakować naszej współczesności. Dzieje się tak z powodu dominowania w postawach ludzkich odruchowości i reaktywności w relacji do rzeczywistości. W celu ilustracji problemu przywołam wybrane fragmenty nauki jednego z chińskich mędrców Han Yu (韩愈) żyjącego w latach 768-824:

\author{
Starożytni chcąc pokazać siłę inteligencji, najpierw \\ rządzili swoim Państwem; ale aby \\ rządzić swoim Państwem, najpierw \\ budowali swoja rodzinę, lecz aby \\ budować rodzinę, najpierw troszczyli się \\ o swoje postępowanie; aby troszczyć się \\ o postępowanie, najpierw przemieniali \\ swe serca, lecz aby przemienić serca \\ najpierw prostowali swe zamiary... \\ Zasady [starodawnych praw] \\ rozumiało się z łatwością i wprowadzało... \\ w czyn... \\ Dziś [natomiast] chce się wysławiać \\ prawa barbarzyńców, co więcej próbuje się je \\ przedkładać nad tamte [starodawne] ... Dziś ci, \\ którzy roszczą sobie prawo do [odnowy], \\ odrzucają Państwo i rodzinę, i przekreślają \\ naturalne więzi, tak iż syn \\ nie szanuje już ojca, poddany \\ nie poddaje się już prawu... \\ Co zatem czynić trzeba?... \\ Trzeba, aby ludzie postępowali jak \\ prawdziwi ludzie ... i aby byli [na nowo] \\ kształceni w nauce [dawnej ]... \\ Miejmy nadzieję, że tak się właśnie stanie¹.
}

1 Cytat został zaczerpnięty z książki L. Giussani, Zmysł religijny, przeł. K. Borowczyk, Poznań 200o, s. 131-132. 
Mimo wielorako manifestującego się zła nadzieję tę możemy posiadać, gdyż zwykle dobra jest więcej, a zrządzenie Bożej Opatrzności sprawia, że w otoczeniu naszym pojawiają się od czasu do czasu ludzie niezwyczajni. Promieniują oni szczególnym blaskiem dobroci, a wzbogaceni żarliwością serca, obdarzają jasnością pogodnej myśli i niezwykłością naturalnej prostoty, z jaką idą ku własnemu przeznaczeniu i każdemu potrzebującemu człowiekowi. Otwarci na nieskończoność, przechodząc przez świat, dzielą się z każdym napotkanym człowiekiem bogactwem darów, jakie Bóg złożył w ich ręce. Spotkania z nimi sprawiają, że wydarza się coś, co normalnie wydaje się niemożliwe. Od czasów średniowiecza nazywani bywają „mistrzami” czy też "gigantami”, na plecach których jest miejsce dla „karłów”, jakimi Hugon od Świętego Viktora nazywał siebie i sobie współczesnych.

Biorąc pod uwagę tylko miniony wiek, można powiedzieć, że jedną z takich postaci, obok św. Jana Pawła II czy błogosławionego kardynała Stefana Wyszyńskiego jest charyzmatyczny myśliciel i wychowawca - ks. Luigi Giussani.

Z listu Jana Pawła II opublikowanego pod datą 22 lutego 2005 r. pt.: Na pogrzeb ks. prałata L. Giussaniego dowiadujemy się, że papież z głębokim wzruszeniem przyjął wiadomość o jego śmierci. Wynikało to z faktu osobistej znajomości i podziwu, jaki Ojciec Święty żywił „dla gorącej wiary «proponującej towarzystwo Chrystusa» bardzo wielu młodym, którzy dzisiaj jako dorośli uznają go za swego duchowego «ojca»" ${ }^{2}$. W tym niezwykle ciepłym i przyjacielskim liście Jan Paweł II zauważa, że „synteza życia i apostolatu «tego żarliwego mediolańskiego księdza» zawarta była w dwóch słowach: «Chrystus i Kościół»”. Papież, doceniając w osobie Giussaniego „obrońcę ludzkiego rozumu”, zauważył też, że był on „dogłębnym znawcą literatury, muzyki i przekonanym promotorem sztuki jako drogi, która prowadzi do Tajemnicy"3.

Niewątpliwie ks. Giussani - na pogrzebie, którego nie przez przypadek homilię głosił kard. Josef Ratzinger, podkreślając, że „Giussani prowadząc osoby nie do siebie, lecz do Chrystusa, rozdał całe bogactwo swego serca, a stając się ojcem wielu, przyczynił się do przemiany świata na lepsze"4 - należy do tych postaci

2 Jan Paweł II, List Ojca Świętego [...”: Na pogrzeb ks. prałata Luigi Giussaniego, Watykan, 22 lutego 2005.

3 Tamże.

4 Tamże. 
XX w., które potrafiły zaświadczyć, że wychowanie człowieka rozumnie wierzącego i jego pełny rozwój, to najważniejsze zadanie i najlepsza inwestycja na przyszłość.

Wyrażając potrzebę popularyzowania wciąż nowych tematycznych opracowań związanych z życiem i działalnością ks. Giussaniego, co w obszarze innych języków, nie wyłączając Polski, jest już faktem ${ }^{5}$, w niniejszym artykule spróbuję jedynie zasygnalizować odpowiedź na kilka podstawowych pytań związanych z jego wielorako manifestującą się działalnością pedagogiczną ${ }^{6}$. Zwrócę uwagę na jego sposób rozumienia pedagogiki i wychowania i przywołam kilka faktów potwierdzających jego wyjątkowość jako człowieka, nauczyciela i wychowawcy.

\section{Krótki rys biograficzny}

Mając na uwadze wyjątkowość posługi ks. Giussaniego w punkcie wyjścia spróbuję zatrzymać się nad kilkoma faktami z jego życia. Bez wątpienia ten uważny i odważny teolog, urodzony w Desio dnia 15 października 1922 r., był postacią znaną i cenioną nie tylko w kręgach kościelnych, ale także w życiu kulturalnym i politycznym. Jednym z wielu jego dokonań było powołanie do istnienia ruchu

5 A. Savorana, Vita di don Giussani, Milano 2013, S. 1351; M. Camisasca, Comunione e Liberazione. Il ricononoscimento (1976-1984). Apendice 1985-2005, San Paolo 2006, s. 328; V. Messori. Dwa sposoby na życie wiarą. Luigi Giussani, w: Pytania o chrześcijaństwo, Kraków 1997, s. 207-218; Comunione e Liberazione. Ruch w Kościele, red. D. Rondoni, tł. W. Janusiewicz, Milano 1998; M. Campagniaro, Wiara to fascynujące spotkanie. Przekaz wiary w społeczeństwie zsekularyzowanym na podstawie pism Luigiego Giussaniego, przeł. M. Wójcik, Warszawa 2017; A. Rynio, Ks. Luigi Giussani. „Ja jestem zerem, Bóg jest wszystkim”, „Przegląd Uniwersytecki KUL”, 3 (2005) s. 24; Wychowanie człowieka otwartego. Rola "Zmysłu religijnego" Luigi Giussaniego w kształtowaniu osoby, red. A. Rynio, Kielce 2001; taż, Przykład niezwykłego etosu Pedagogicznego (ks. Luigi Giussani, 1922-2005), w: Człowiek u progu trzeciego tysiąclecia. Zagrożenia i wyzwania, t. 2, red. M. Plopa, Elbląg 2007, s. 211-228; taż, Chrześcijańska pedagogia nadziei ks. Luigi Giussaniego, „Roczniki Pedagogiczne”, t. 1 (2009) s. 67-82; taż, Fr Luigi Giussani's Concept of Education - an Outline, „The Person and the Challenges", 1 (2011) nr 2, s. 149-165, DOI: 10.15633/pch.858; taż, Specyfika wychowania do wiary $w$ posłudze założyciela ruchu Comunione e Liberazione - Ks. Luigi Giussaniego, w: Universitati serviens. Księga pamiątkowa ku czci Księdza Profesora Stanisława Wilka SDB, red., ks. J. Walkusz, M. Krupa, Lublin 2014, s. 667-680.

6 Autorce niniejszej publikacji dane było i dalej jest pozostawać pod formacyjnym wpływem tej postaci. 
Comunione e liberazione. Dziś ruch ten istnieje na wszystkich kontynentach w ponad dziewięćdziesięciu krajach, nie wyłączając Polski, gdzie znany jest pod nazwą Komunia i Wyzwolenie.

Niewątpliwie w osobie ks. Giussaniego, który wzorem św. Pawła wszystko kazał badać, a zachowywać jedynie to co szlachetne, mieliśmy do czynienia z kimś, kto wszedł do historii Kościoła i religii jako świadek. Była to postać charyzmatyczna i wyjątkowa. Przyznają i szanują go nawet ci, którzy nie uznawali i nie uznają wartości jego przesłania.

Interesująca jest historia jego drogi życia. Kiedy próbuje się ją analizować, okazuje się, że jego ojciec mimo ogromnego szacunku, jaki żywił do kapłanów, był przekonanym socjalistą, a matka - jak sam wyznaje - „kobietą wyjątkowo piękną, o wielkiej i prostej wierze". Od ojca Giussani przejął inteligencję i wrażliwość, a także pasję dla życia i piękna, która stała się później jednym z centralnych punktów metody wychowawczej ruchu Comunione e Liberazione. Od matki przejął wrażliwość na każdego potrzebującego pomocy. Jego dom rodzinny odznaczał się klimatem ogromnego szacunku wobec osoby oraz czynnym wychowaniem do ciągłego ożywiania prawdziwych wymiarów serca i rozumu. To dzięki ojcu i matce Giussani uczył się postrzegać rzeczywistość jako miejsce odsłaniania się człowiekowi tajemnicy Boga. Jego matka, poświęcając całe swoje życie wychowaniu dzieci, dała im przykład wiary wielkiej, a jednocześnie bardzo prostej, realizowanej w codzienności. Nieustannie zwracała uwagę na ludzi potrzebujących, a jednocześnie umiała pokazywać piękno świata, a tym samym podziwiać jego Stwórcę. Wielokrotnie w ciągu dnia powtarzała: „Jezus cię widzi”, „zrób to dla Jezusa,” zachęcała przy tym do solidnej pracy nad sobą ${ }^{7}$. Opowiadała też i analizowała minione zdarzenia, uświadamiając, że chrześcijaństwo przedstawia się jako zaistniałe wydarzenie, którym się żyje współcześnie. Tak więc to rodzice rozbudzili w swoim synu wrażliwość wobec otaczającego świata i pobudzili go do refleksji ${ }^{8}$. W procesie odkrywania Boga jako zasady jednoczącej i wyjaśniającej całą rzeczywistość („Bóg wszystko we wszystkim i wszystkim we wszystkich") niebagatelne miejsce przypada

7 A. Savorana, Vita di don Giussani, s. 21; Ksiądz Giussani (1922-2005), Szukał piękna, znalazł Chrystusa, komunia i wyzwolenie, https://pl.clonline.org/ksi\% $\% \mathrm{C}_{4} \% 85 \mathrm{dz}$ -giussani, dostęp: 1.06.2021.

8 M. Camisasca, Comunione e Liberazione. Le origini (1954-1968), San Paolo 2001, s. 38. 
Niższemu Seminarium Duchownemu w Venegono, do którego Giussani wstąpił bardzo wcześnie, mając zaledwie 11 lat. Jak sam po latach wyznał, spotkał tam wybitnych profesorów takich jak: Gaetano Corti, Giovanni Colombo, Carlo Colombo, Carlo Figini. Ci profesorowie i autorzy przez nich polecani jak: John Henry Newman, Antonio Francesco Davide Ambrogio Rosmini Serbati, Giovanni Francesco Stoppani, Alessandro Manzoni uczyli i rozwijali jego inteligencję, wolność i wierność Kościołowi. Po święceniach kapłańskich w 1945 r. Giussani głosił wykłady w Seminarium Duchownym na Wydziale Teologicznym Archidiecezji Mediolańskiej, specjalizując się - co wówczas było rzadkością - w teologii wschodniej i protestanckiej. Interesowały go: rozumny charakter aktu wiary i motywacja przynależności do Kościoła. W 1954 r., po obronie doktoratu, zrezygnował z pracy wykładowcy i robienia kariery na rzecz obecności wśród młodzieży. Z własnego wyboru został nauczycielem religii w Liceum Klasycznym im. Berchet w Mediolanie. Z pracy tej jeszcze w latach pięćdziesiątych zrodziła się organizacja o nazwie Gioventu studentesca (Młodzież uczniowska), która potem w latach siedemdziesiątych przerodziła się w ruch kościelny o nazwie Comunione e Liberazione (Komunia i Wyzwolenie).

\section{Istota pedagogiki i wychowania}

Ks. Giussani odznaczał się bardzo trzeźwym i realistycznym spojrzeniem na człowieka i jego wychowanie. W 1977 r. ppublikował pracę Ryzyko wychowawcze, w której prezentował swoje refleksje nad dwudziestoletnim doświadczeniem w roli wychowawcy. W tatach następnych była to jedna z najczęściej czytanych i tłumaczonych książek (ponad 40 wersji językowych). Podkreślał wartość osoby jako istoty rozumnej i wolnej, jego postawa charakteryzowała się całkowitym zawierzeniem Bogu i wielką miłością do człowieka. Przez całte życie, wychowując do wiary w Boga i twórczej obecności w świecie tysiące ludzi na świecie, korzystając z badań nad działalnością amerykańskiego teologa protestanckiego Reinholda Niebuhra, o pedagogice mówił jako o „sztuce uczenia rzeczy trudnych ludzi jeszcze niedojrzałych"9. Wychowanie zaś naj-

9 Il senso cristiano dell'uomo secondo Reinhold Niebuhr [Zmysł chrześcijański człowieka wg Reinholda Niebuhra Teologia Protestante Americana [Amerykańska teologia protestancka]) cyt. za: Ksiądz Giussani (1922-2005), Szukał piękna, znalazł Chrystusa. 
częściej rozumiał jako pomoc udzielaną duchowi ludzkiemu we wchodzeniu w kontakt z rzeczywistością ujętą całościowo oraz w zrozumieniu czynników stanowiących tę rzeczywistość ${ }^{10}$. Giussaniemu chodziło o wychowanie, które jest prawdziwe, to znaczy: odpowiadające potrzebom człowieka ${ }^{11}$ Największą troską tego wychowawcy było podjęcie wysiłku, by „wychować serce człowieka takim, jakim stworzył je Bóg"12. Za najważniejsze trzy elementy tego wychowania Giussani uznawał:

1) „aby w procesie wychowania w adekwatny sposób przedstawiać przeszłość" ${ }^{\prime 13}$;

2) „przeszłość może być proponowana młodym ludziom tylko wtedy, gdy jest przedstawiana w ramach ich teraźniejszych przeżyć, które podkreśliłyby jej zgodność z ostatecznymi wymogami serca. To znaczy, w ramach ich teraźniejszego doświadczenia, które miałoby swoje uzasadnienie, które byłoby dla nich zrozumiałe"114;

3) „Prawdziwe wychowanie powinno być wychowaniem do krytycznego myślenia"15. Brak któregoś z tych czynników: tradycji, przeżywanej teraźniejszości, która proponuje przeszłość i ją uzasadnia, oraz krytyki sprawia, że „młody człowiek jest jak mały, kruchy liść, oderwany od macierzystej gałęzi, (Dokąd lecisz? pytał poeta Leopardi), ofiara porywistego wiatru, własnej niestałości, ofiara opinii publicznej manipulowanej przez możnych tego świata"16.

Giussaniemu chodziło o wyzwolenie młodych z mentalności zniewolenia, z uniformizacji, bezmyślnego naśladownictwa, które czyni z nich intelektualnych niewolników innych ludzi. Rozumiejąc wychowanie jako wprowadzanie

10 L. Giussani, Ryzyko wychowawcze, przeł. D. Chodyniecki, Kielce 2021 (okładka strona zewnętrzna).

11 Tamże s. 15.

12 Tamże.

13 Tamże s.16.

14 Tamże s.17.

15 Tamże s. 17; M. Flis-Jaszczuk, Rec. Luigi Giussani, Ryzyko wychowawcze jako tworzenie osobowości i historii, Kielce: Wydawnictwo „Jedność, 2002, „Roczniki Nauk Społecznych", 30 (2002) z. 2 s. 237.

16 L. Giussani, Ryzyko wychowawcze, s. 20. 
w rzeczywistość ujętą całościowo, rację istnienia osoby upatrywał w jej sercu, w które natura wyposaża każde ludzkie dziecko.

Tak rozumiane wychowanie wymaga zastosowania odpowiedniej metody i zaczyna się od Ja istniejącego w określony miejscu i czasie. Jego bazę wyjściową stanowi to, kim człowiek jest i jakie są jego predyspozycje i przypadłości. Do istoty tak rozumianego wychowania należy otwartość na rzeczywistość, czyli to, co realnie istniejące, piękne, dobre i prawdziwe. Dla Giussaniego nie było najistotniejsze to, czego młodzi potrafią dokonać, ale to kim są, jakie są ich predyspozycje i kim potrafią być. Dlatego swą bezkompromisową postawą życia i nauczaniem uformował tysiące młodych i dorosłych na całym świecie. Niewątpliwą pomocą w tym „uczeniu rzeczy trudnych ludzi jeszcze niedojrzałych" była jego bogata twórczość literacka, wyjątkowy charyzmat pedagogiczny i założony przez niego w 1954 r. ruch Comunione e Liberazione. Pomocą były też niezliczone wprost dzieła, które z tego charyzmatu się zrodziły. Wystarczy wspomnieć o międzynarodowym miesięczniku ruchu Comunione e Liberazione „Tracce” [Ślady], mającym kilka edycji językowych, w tym także polską, platformę internetową zrzeszającą tysiące dzieł Compagnia delle opere czy zainicjowaną przez ks. Giussaniego w 1994 r. serię wydawniczą zawierającą najznakomitsze dzieła z zakresu poezji, prozy oraz eseistyki, w których różni autorzy przedstawiają sposób, w jaki duch chrześcijański mierzy się z problemami egzystencji i kultury. Wśród autorów tej serii znaleźli się m.in. Giacomo Leopardi, Thomas Stearns Elot, Emmanuel Mounier, John Henry Newman, Vittorio Messori czy klasycy jak Miguel de Cervantes, Fiodor M. Dostojewski, William Shakespeare, Dante Alighieri ${ }^{17}$.

\section{Ksiądz Giussani jako wyjątkowy nauczyciel i wychowawca}

Wyjątkowość ta manifestowała się poprzez to, kim był i w jaki sposób wykładał, pisał, nauczał i działał. Będąc człowiekiem prawdziwie pokornym i nie pozwalając nazywać się mistrzem - rodził mistrzów i był „wszystkim dla wszystkich, aby ocalić przynajmniej niektórych". Kochał Pana Boga, człowieka i Kościół.

17 Wykaz wszystkich pozycji na stronie https://it.clonline.org/libri/libri-dello-spirito-cristiano. Warto też odwiedzić polską stronę https://pl.clonline.org/ksi\%0C4\%85dz-giussani. 
Ks. Giussani katechetą był przez 10 lat, a duszpasterzem, myślicielem i niekwestionowanym autorytetem w sprawach wiary, moralności i wychowania przez całe życie. Od 1964 r. - pełnił funkcję profesora Uniwersytetu Katolickiego w Mediolanie. Przez wiele lat prowadził ogólnouniwersyteckie wykłady ze Wstępu do teologii, które publikowano w formie książek wydawanych w tysięcznych nakładach. Swoją katedrę zachował aż do 1990 r. Na jego dorobek naukowy składa się wiele interesujących prac i artykułów poświęconych m.in. teologii fundamentalnej, ontologii, podstawom antropologii, moralności i wychowaniu, a także znaczeniu literatury i muzyki w życiu religijnym. Wypowiadał się również na tematy społeczne ${ }^{18}$. Istotną dla niego samego jest seria trzech książek, na która składają się: Il senso religioso ${ }^{19}$; All'origine della pretesa cristiana $^{20}$ i Perchè la Ciesa ${ }^{21}$. Trylogia ta powstała w latach 1986-1992 i stała się podstawą cyklu wychowawczo-katechetycznego, który stanowił bazę do pracy podczas cotygodniowych spotkań „Szkoły wspólnoty” członków ruchu². Pierwsza część cyklu, pt. Zmysł religijny, okrzyknięta została bestsellerem i przetłumaczona na 23 języki, prezentowana była w różnych miejscach świata. W tym miejscu warto odnotować, iż Zmysł religijny był przedmiotem międzynarodowej sesji zorganizowanej na Katolickim Uniwersytecie Lubelskim, przez Alinę Rynio. Materiały z tej sesji zostały opublikowane przez wydawnictwo "Jedność" w 2001 r. i noszą tytuł Wychowanie człowieka otwartego. Rola zmysłu religijnego ks. Luigi Giussaniego w kształtowaniu osoby. W 2002 r. także w tym wydawnictwie ukazała się wspominana wyżej ważna szczególnie dla pedagogów, katechetów i rodziców książka Ryzyko wychowawcze ${ }^{23}$. Z licznych publikacji ks. Giussaniego w języku polskim dostępne są jeszcze m.in.: Śladami chrześcijańskiego

18 L. Giusani, Zaangażowanie chrześcijanina w świecie, w: H. Urs von Balthazar, L. Giussani, Miejsce chrześcijanina w świecie, przeł. K. Kubis, A. Porębski, Kraków 2003, s. 115-184; L. Giusani, Zmysł Boga a człowiek współczesny. „Kwestia ludzka” i nowość chrześcijaństwa, przeł. K. Borowczyk, „Ślady”, 1997, nr 5-6 (38-39), s. 12-13.

19 L. Giussani, Il senso religioso, t. 1, Milano 1986.

20 Tenże, All'origine della pretesa cristiana, t. 2, Milano 1988.

21 Tenże, Perchè la Ciesa? La pretesa rimane, t. 3, Milano 1990.

22 Comunione e Liberazione. Ruch $w$ Kościele, s. 114.

23 L. Giussani, Ryzyko wychowawcze jako tworzenie osobowości i historii, przeł. A. Surdej. Kielce 2002; Drugiego przekładu dokonał D. Chodyniecki. Nosi ono tytuł Ryzyko wychowawcze, Kielce 2021. 
doświadczenia ${ }^{24}$, Czas i Świątynia ${ }^{25}$, Doświadczenie jest drogą do prawdy ${ }^{26}$, Cała ziemia pragnie Twojego oblicza ${ }^{27}$, Chrześcijaństwo jako wezwanie ${ }^{28}$, Dlaczego Kościót? ${ }^{29}$, Zostawić ślady w historii świata ${ }^{30}$, Wydarzenie wolności ${ }^{31}$.

Dla wielu ks. L. Giussani był i pozostanie postacią charyzmatyczną, kimś, kto z łatwością rozpoznawał Boga żywego i obecnego i uczył świadomego przeżywania chrześcijaństwa w wymiarze misyjnym, także w życiu kulturalnym i społeczno-politycznym. Biografowie i ci, którzy go spotkali i poznali, zauważają, że najważniejszy był dla niego Chrystus i to, co od Niego pochodzi. Dlatego też mógł on powiedzieć o swoim życiu, „iż ma nadzieję, że toczy się ono zgodnie z tym, czego Bóg od niego oczekiwał, a każda chwila jego życia była poszukiwaniem chwały Chrystusa i pokazywaniem Jego osoby”. Owo „pokazywanie” polegało na uobecnianiu tego, co Bóg już uczynił.

Sobie współczesnym dał się poznać nie tylko jako nauczyciel religii czy profesor Uniwersytetu Sacro Cuore w Mediolanie, ale również jako założyciel i przewodniczący wyrosłych z ruchu stowarzyszeń kościelnych: Bractwa Comunione e Liberazione zrzeszającego ponad 67 tys. osób dorosłych oraz żyjącego dziewictwem i nieustanną pamięcią Pana w świecie i miejscu pracy - Świeckiego Stowarzyszenia Memores Domini i Bractwa Św. Józefa.

Dla psychologów i pedagogów zastanawiające jest, z czego rodziło się tak wielkie bogactwo osoby ks. Giussaniego i skąd brała się jego wychowawcza atrakcyjność? Dla tych, którzy go znali, odpowiedz jest prosta: ze sposobu przeżywania spotkania ze Słowem, „które ciałem się stało i zamieszkało między nami". Szczegółowo o swoim spotkaniu z Chrystusem i wyrosłym z niego dziele,

24 Tenże, Śladami chrześcijańskiego doświadczenia, przeł. K. Klauza, red. i wstęp do polskiego wydania Z. Bradel, Warszawa 1988.

25 Tenże, Czas i Świątynia. Bóg i człowiek, przeł. K. Borowczyk, słowo wstępne do polskiego wydania F. Kard. Macharski, Częstochowa 1997.

26 Tenże, Doświadczenie jest drogą do prawdy, przeł. D. Chodyniecki, Kielce 2003.

27 Tenże, Cała ziemia pragnie Twojego oblicza, przeł. D. Chodyniecki, Kielce 2004.

28 Tenże, Chrześcijaństwo jako wyzwanie. U źródeł chrześcijańskiego roszczenia, przeł.

D. Chodyniecki, Poznań 2002.

29 Tenże, Dlaczego Kościół?, przeł. D. Chodyniecki, Poznań 2004.

30 L. Giussani, S. Alberto, J. Prades, Zostawić ślady w historii świata, Opole 2011.

31 Tenże, Wydarzenie wolności. Rozmowy ze studentami, przeł. D. Chodyniecki, Opole 2020. 
jakim jest Ruch Comunione e Liberazione ks. Giussani zaświadczył na placu Św. Piotra w Rzymie w dniu 30 maja 1998 r. Mówił wówczas:

To dzięki prostocie serca doświadczyłem i uznałem wyjątkowość Chrystusa z tą natychmiastową pewnością, jaka zdarza się w obliczu niekwestionowanej i niezniszczalnej oczywistości czynników i momentów rzeczywistości, które - z chwilą wejścia w przestrzeń osoby - dotykają samej głębi serca. [...] Człowiek nie osiąga wielkości dzięki swoim zabiegom; wielkość przychodzi z łaski Boga, jak piękny dzień (Camus, Zeszyty). Dla mnie wszystko wydarzyło się jak zaskoczenie pięknego dnia, kiedy nauczyciel w pierwszej klasie licealnej - miałem wtedy 15 lat - przeczytał i wyjaśnił pierwszą stronicę Ewangelii św. Jana. Wówczas czytano ją obowiązkowo pod koniec każdej Mszy Świętej; słyszałem ją więc wcześniej tysiące razy. Ale nadszedł piękny dzień: wszystko jest łaską. [...] Po czterdziestu latach, czytające ten fragment, zdołałem uchwycić, co się wydarzyło, kiedy ów nauczyciel wyjaśniał pierwszą stronicę Ewangelii św. Jana: Słowo Boga, to w czym wszystko ma istnienie, stało się ciałem - mówit - dlatego piękno stało się ciałem, dobro stało się ciatem, sprawiedliwość stała się ciałem, miłość, życie, prawda stały się ciałem: byt nie przebywa w platońskim «hiperuranium», [chodzi o świat ponad niebem, gdzie przebywają idee] byt staje się ciatem, jest jednym $z$ nas.[...] Słowo stało się ciałem. Byt (piękno, prawda i dobro) nie tylko nie pogardził ciałem, by przyoblec w nie Swą doskonałość i podjąć troski człowieczego życia, ale więcej - przyszedł umrzeć za człowieka: Przyszedł do swoich, a swoi go nie przyjęli, zapukał do swojego domu, a nie poznano go. I to wszystko. Bo tym było odtąd ogarnięte moje życie: jako pamięć uparcie drążąca moje myśli i jako bodziec do przewartościowania banalnej codzienności. Chwila nie była już dla mnie czymś banalnym. Wszystko, co było - a więc wszystko co było piękne, prawdziwe, pociągające, nawet potencjalnie tylko - znajdowało swoją rację istnienia w tym orędziu, w pewności obecności i nadziei, która mobilizuje i pozwala objąć każdą rzecz ${ }^{32}$.

Chcąc opisać ten niczym niepowstrzymany impet, jaki zagościł w sercu Giussaniego od momentu rozpoznania Chrystusa jako „prawdy wszystkiego", należy użyć pojęcia „pragnienie". Jest ono udziałem każdego prawdziwego misjonarza,

32 L. Giussani. W prostocie mego serca radośnie oddatem Ci wszystko. Świadectwo księ$d z a$ [...] podczas spotkania z Ojcem Świętym. Plac Św. Piotra, 30 maja 1998, w: Comunione e Liberazione. Ruch w Kościele, s. 110-112. 
a wyraża się w tym, żeby wszyscy poznali to, co on poznał i żeby dla wszystkich „mógł wzejść ów piękny dzień". Jako drogę prowadzącą do poznania Chrystusa i przeżycia spotkania z Nim, ks. Giussani proponował doświadczenie jedności. Manifestuje się ono „w znaku zgody, przyjaźni i wspólnoty tych, którzy idą za Chrystusem i tym, co od Niego pochodzi”. Uczył, że „kiedy to uznajemy, wtedy jedność ta zaczyna pulsować i nasze życie staje się bardziej ludzkie. Wspólnota, rozszerzana bez granic, stanowi tajemnicę tej tożsamości, dzięki której, i w której mogę powiedzieć Chrystusowi z drżeniem, lękiem i miłością: Ty!"33.

Nic zatem dziwnego, że

wspólnota, towarzystwo, gdzie wydarza się spotkanie z Chrystusem, jest miejscem przynależności naszego ja, miejscem, od którego uczy się ono ostatecznego sposobu odbierania i rozumienia rzeczy, ich intelektualnego przyswajania i osądzania, planowania, projektowania, decydowania, robienia. Nasze ja przynależy do tego ciała, którym jest nasze towarzystwo i z niego czerpie kryterium w mierzeniu się ze wszystkim. Dlatego nasz punkt widzenia nie chodzi swoimi drogami, lecz zobowiązuje się do porównania i w porównaniu okazuje posłuszeństwo wspólnocie, towarzystwu ${ }^{34}$.

Całą, przebogatą działalność wychowawczą ks. Giussaniego dobrze opisują jego własne słowa:

Jedyną racją, dla której zrobiliśmy to, co zrobiliśmy (i będziemy to robić, dopóki Bóg nam pozwoli), jedyną racją dla naszych zabiegów jest to, żeby Go poznali, żeby ludzie poznali Chrystusa. Bóg stał się człowiekiem, przyszedł do swoich: to, że swoi go nie znają, jest najcięższym grzechem, jest zdecydowanie największą niesprawiedliwością ${ }^{35}$.

\section{Preferowane sposoby wychowania}

Rozumiejąc, wychowanie to wprowadzanie w to, co prawdziwe zawsze i wszędzie - mając na uwadze choćby tylko treści zawarte w jego publikacjach takich jak wspomniane Ryzyko wychowania czy Zmyst religijny - jest ono wychowaniem

33 Tamże.
34 Tamże.
35 Tamże. 
potwierdzającym to, co jest, co istnieje realnie. Giussani uczy, że żyjący realnie człowiek wie, że „najpierw go nie było, a teraz jest”. Zdaje sobie sprawę, że „może być albo mało znaczącym punkcikiem niesionym przez nurt historii, nieuchronnie pozostającym na łasce władzy, albo będąc relacją z owym tajemniczym X, niekończącym się horyzontem każdej myśli i każdego działania, jest tym, kim być powinien, a jego działanie można nazwać ludzkim tzn. wolnym"36. Owo tajemnicze $\mathrm{X}$ jest nośnikiem, wyjaśniającym rzeczywistość i odpowiedzią na ludzką potrzebę bycia prawdziwym, wolnym i szczęśliwym na zawsze. Tym X, jest Słowo, które stało się człowiekiem i zamieszkało między nami - to Jezus Chrystus, prawdziwy Bóg i prawdziwy człowiek, narodzony w czasie, z Maryi Dziewicy. Objawiając imię Boga i będąc ideałem i wzorem dla każdej ludzkiej egzystencji, niesie On wyzwolenie od niewoli grzechu, samotności i zagubienia. Będąc „Prawdą, Drogą i Życiem”, wszystkiemu przywraca znaczenie, a dla wychowania staje się „ideałem bez końca”. Jego imieniem jest „miłość i miłosierdzie”. Pozostawanie w Nim czyni byt ludzki nowym stworzeniem. Daje mu nowy sposób patrzenia, myślenia, afektywności i działania. Ten nowy sposób bycia wyraża się w sprawiedliwości, która jest miłością, we właściwych relacjach międzyludzkich, w pojmowaniu wolności, przyjaźni czy pracy. Wyraża się w umiejętności osądu i życiu zgodnym z Bożym zamysłem. Naśladujący Jezusa z czasem zaczyna rozumieć, że każda praca wyraża się w świadomej relacji do siebie, do swojej duszy i swojego ciała, do ojca, matki, dziecka, pola, zakładu pracy, domu i że nie ma żadnej rzeczy, żadnej relacji, która nie byłaby pracą. Tak rozumiana praca podobnie jak wychowanie otwarte, Objawienie rodzi się z przyjaźni z Bogiem i rozwija się jako umiłowanie i pasja towarzysząca wchodzącemu w relacje z jakąkolwiek rzeczą. Stąd też chcąc żyć po chrześcijańsku, nie musimy rezygnować z niczego, ale zmienić relację ze wszystkim.

Giussani, charakteryzując wychowanie jako czynność otwartą na hipotezę Objawienia, wychodzi z założenia, iż kierujący się poczuciem realizmu i rozumnością człowiek jest zdolny do osądu i przyjmowania postawy krytycznej ${ }^{37}$. Zdolność ta wyraża się w dążeniu do bycia realistą i traktowania świata jako miejsce objawiania się Tego, który go stworzył. Ks. Giussani, ucząc realistycznego patrzenia na własną osobę w działaniu, wyraża przekonanie, iż „racją bycia osoby jest

36 Tamże.

37 Szerzej piszę na ten temat w art. Wychowanie otwarte na hipotezę Objawienia, w: Wychowanie człowieka otwartego, s. 88-97. 
dążenie do prawdy, sprawiedliwości, wolności i szczęścia bez końca"38. Sądzi on, iż człowiek swą pewność moralną czerpie z poznania prawdy o sobie i otaczającym go świecie. Przyjmując zaś, że wiara jest darem, troszczył się o jej dojrzałość, wyrażającą się w tym, że „Chrystus przenika wszystkie rzeczy i jest obecny w historii poprzez osobowość ochrzczonego i komunię z braćmi"39.

Bóg był dla niego rzeczywistością, którą można było spotkać. Uczył, że „Obecność ta winna stawać się dla człowieka „hipotezą pracy”, bez której nie jest on w stanie zrozumieć siebie, drugiego i otaczającego świata. Samą wiarę definiował jako „coś, co rodzi się z zapatrzenia”, co jest „wędrówką spojrzenia” i staje się adekwatną odpowiedzią na ostateczny sens egzystencji. Według niego tak formowany człowiek nie tylko jest zdolny do krytyki i osądu, ale pokonuje pozorną dychotomię między wiarą a rozumem, życiem a działaniem. Wychowywany przez Giussaniego do wiary człowiek wie, że nie jest miarą rzeczywistości, a kryteria osądu, jakie odkrywa w swoim sercu, są mu dane przez kogoś innego. Jest wychowywany do bycia uważnym, odważnym i zdolnym do podjęcia „ryzyka wolności, która otwiera go na oścież jak okno, na każdy aspekt rzeczywistości, także ten nieznany i tajemniczy" ${ }^{40}$. Wie też, że dla prawdziwego i pełnego rozwoju potrzebuje autorytetu, kogoś, kto uosabia ową „hipotezę wyjaśniającą rzeczywistość i żyje doświadczeniem wiary i miłości". Według włoskiego myśliciela, w wychowaniu ważna jest świadomość praw i powinności, rozwijanie zmysłu krytycznego, kategorii problemu i poczucia przynależności, nie wyłączając miłości do prawdy, gotowości do przemiany, ofiary i wyrzeczenia, akceptowania drugiego w jego odmienności, świadomości misji, odpowiedzialności, współdzielenia potrzeb czy konieczności pracy ascetycznej ${ }^{41}$.

\section{Zdarzenia wychowujące}

Dla włoskiego myśliciela było oczywiste, że celem jego życia jest Chrystus, obecny we wspólnocie wierzących, znany i rozpoznawany jako Pan czasu

38 Ksiądz Giussani (1922-2005), Szukał piękna, znalazł Chrystusa.

39 A. Rynio, Wychowanie otwarte na hipotezę Objawienia, s. 90.

40 Tamże.

41 Kwestie te omawiam szczegółowo we wcześniejszym artykule: Wychowawcza metoda ks. L. Giussaniego, w: Wychowanie człowieka otwartego, s. 98-102. 
i historii, który poprzez wcielenie stał się towarzyszem jego ludzkiej drogi. Nic zatem dziwnego, iż formowany przez niego podmiot, świadom chrztu i bierzmowania, czuje się powołany do odczytania na nowo, i zgodnie z Tradycją, całego chrześcijańskiego doświadczenia. Kościół traktuje on jako miejsce zbawienia pochodzącego od Chrystusa. Równocześnie ks. Giussani uczył, że człowiek ochrzczony, dzieląc się doświadczeniem wiary, ma budować wspólnotę chrześcijańską tam, gdzie jest. Uczył też, iż życie ludzkie jest tkanką niezliczonej liczby zdarzeń i spotkań, poprzez które człowiek może być wychowywany. Wymaga to jednak od niego wielkiej pokory. Takim zdarzeniem wychowującym może być odkrycie sposobu wyrażania potrzeby poznawczej rozumu, doznanie estetyczne, przeżycie przyjaźni, piękna, miłości, zetknięcie się z dobrem bądź jego świadczenie, urodzenie dziecka, własne lub cudze nieszczęście czy też śmierć kogoś bliskiego. Zdarzeniem takim jest też odpowiednie komunikowanie przeszłości w teraźniejszości i zetknięcie się z autorytetem. Ten ostatni, podobnie jak Tradycja ujmowana krytycznie, jest ważny, ponieważ „natura ustanowiła go jako normę każdego prawidłowego rozwoju”. W wychowaniu rozumianym przez Giussaniego jako odpowiednie komunikowanie przeszłości przeżywanej w teraźniejszości i poddawanej pewnej krytyce istnieje potrzeba posiadania mistrza i nauczyciela, który wprowadza w to, co prawdziwe zawsze wszędzie i dla każdego. Potrzeba kogoś, kto cieszyłby się autorytetem i pomógł odczytać kryteria osądu i rozwinąć tak bardzo potrzebny ludziom młodym zmysł krytyczny. Potrzeba kogoś, kto pomógłby dzieciom i młodzieży zrozumieć samych siebie. Według Giussaniego potrzeba nauczycieli, którzy nie tylko nauczają, ale też wychowują w duchu praw i powinności, którymi żyją sami. Potrzeba tych, którzy wychowują w duchu troski o godność i dobro każdego człowieka i ukazują godziwe warunki życia i pracy. Przywrócenie wychowawczej obecności w procesie wychowania jest koniecznością, ponieważ ważnym kryterium ludzkiego rozwoju jest to, że osoba uczy się jedynie wtedy, gdy „idzie za”. Kiedy jest dzieckiem, czyni to niejako instynktownie, gdy staje się bardziej dojrzała, angażując w to wolę, inteligencję i afektywność. Osoba uczy się, gdy czuje, że jest szanowana dla wartości, jaką w sobie nosi, gdy pozwala się jej być twórczą, samodzielną i swobodną ${ }^{42}$.

42 A. Rynio, Wychowanie otwarte na hipotezę Objawienia, s. 91. 


\section{Elementy konstytuujące osobowość wychowującego i wychowywanego}

Autor Ryzyka wychowawczego wychodząc z założenia, iż wychowanie odpowiadające na potrzebę posiadania hipotezy objaśniającej rzeczywistość, jest komunikowaniem siebie samego, zwraca uwagę na istotne elementy konstytuujące osobowość wychowującego i wychowywanego. Nie sposób omówić je wyczerpująco. Zatrzymam się więc na kilku wybranych: Oto one: miłość do prawdy, doświadczenie żywej wiary, w tym wiary w istnienie dobra trudno osiągalnego (nadzieja), potrzeba przynależności, troska o dobro własne i innych, przeżycie wolnego wyboru, odpowiedzialność za to, do czego wzywa rzeczywistość, współdzielenie potrzeb z innymi na zasadzie międzyludzkiej solidarności, potrzeba posiadania własnej tożsamości i wrośnięcia w tradycję, potrzeba posiadania mistrza, dowartościowanie tego, co „tu i teraz”, otwartość na przyszłość, konieczność pracy nad sobą, uczenie się postawy bycia korygowanym i korygowania innych, wreszcie potrzeba przebaczania i akceptowania drugiego w jego inności.

Zauważmy, iż nie są to kwestie, od których możemy abstrahować, podejmując zaszczytną, choć trudną sztukę wychowania człowieka. Niewątpliwie przyjęcie Chrystusa i tego, co od Niego pochodzi, czyni proces wychowania łatwiejszym i skuteczniejszym, gdyż daje stabilny fundament i wskazuje na adekwatną metodę wychowania. Natomiast pamięć o Chrystusie, na którą ks. Giussani zwracał szczególną uwagę, pozwala dowartościować wszystko, co się wydarza w życiu i historii i jest potwierdzeniem tego bogactwa, jakie wypływa z doświadczenia chrześcijańskiego. Pamięć ta, wzmacniana poprzez modlitwę i udział w liturgii, rodzi jedność osoby, świadomość powołania i jedność chrześcijan, która uobecnia się i wyraża we wspólnotowości i jedności z prawowitym autorytetem kościelnym, nie mówiąc o dojrzałych osobowościach gotowych miłować nawet nieprzyjaciół. Według Giussaniego pójście z Kościołem drogą wiary w Boga, który jest „wszystkim we wszystkim”, i Chrystusa, który jest „wszystkim we wszystkich", pozwala człowiekowi być tym, kim być powinien. Chroni go od nihilizmu, bezsensu, bylejakości, lęku, wyobcowania, anarchii, sceptycyzmu, beznadziei, egoizmu i nieodpowiedzialności. 


\section{Związek wychowania z wolnością, sumieniem i tradycją.}

Na zakończenie tego szkicu pozostaje mi jeszcze odpowiedzieć, jaki jest stosunek tak rozumianego wychowania do wolności, sumienia i tradycji? Z analiz już poczynionych wynika, iż proponowane przez ks. Giussaniego wychowanie, uwzględniając potrzebę integralnego i harmonijnego rozwoju osoby, dowartościowuje rozum widziany w kategorii możliwości. Dowartościowuje też umiejętność czytania sensu znaczeń wewnątrz rzeczywistości. Nie pomija przy tym wolności, prawego sumienia, uwagi, komunijnego charakteru realizowania się Bożego planu, ryzyka, potrzeby wychowania uczuć czy odpowiedzialności za to, do czego w danym momencie wzywa rzeczywistość. Mamy tu do czynienia z wychowaniem wrośniętym w tradycję i odzyskiwanie tego, co odziedziczyło się po przodkach przy równoczesnym dowartościowywaniu teraźniejszości i otwarciu na przyszłość. Takie wychowanie jest potwierdzaniem tego, co jest, co jest realne. Ma ono swój ideał, który istnieje w czasie i jest ideałem bez końca, a mimo to da się uchwycić. Tym ideałem jest Bóg, który stał się człowiekiem. Fakt ten historycznie był i dalej jest powodem zgorszenia dla wielu podzielających mentalność kulturową naszej cywilizacji. Według Giussaniego nierozpoznawanie tego ideału czyni nas kłamcami i sprawia, że zamiast prawdy widzimy kłamstwo i wedle niego żyjemy. Natomiast posiadanie ideału, jakim jest Chrystus, każe pracować nad myśleniem, samoświadomością i moralnością, nad umysłem i sercem i każe podjąć ascezę, która jest tylko pozornym pójściem przeciw sobie.

Za niezwykle cenne w przywołanej tu zaledwie w zarysie wizji wychowawczej należy uznać nie tylko jej biblijne podstawy, ale również jej klasyczno-filozoficzne tło refleksji i możliwość praktycznego wykorzystania. O wychowaniu tym, podobnie jak o wezwaniu chrześcijańskim, można powiedzieć, iż jest jasną inicjatywą wobec każdego pojedynczego człowieka. Jest ono proste i zasadnicze. Zakłada ideał i pragnienie, które je podtrzymuje, a ponadto zakłada spotkanie, dialog, rozumność, wiarę, miłość, wolność, działanie, konkretność, integralność, kulturę, tradycję, współdziałanie, przyjaźń, osobiste zaangażowanie, doświadczenie niemożliwej odpowiedniości, funkcjonalność, wychowanie do krytyki, osobistą weryfikację tego, co jest proponowane i autorytet. Wychowanie, jako otwarcie na całą rzeczywistość, dokonuje się przy współudziale rodziny, szkoły, 
Kościoła i osobistej aktywności wychowanka. Jest otwarte na życie społeczne oraz zawodowe i domaga się twórczej obecności ochrzczonych w środowisku ${ }^{43}$.

Niewątpliwie w osobie księdza Giussaniego rozpoznać można było wyjątkowego pedagoga i przyjaciela wielu, a zarazem człowieka opatrznościowego, którego charakteryzowała porywająca miłość do tajemnicy człowiek i umiłowanie tego, co człowiek może urzeczywistnić i uczynić centrum swojej historii. Chrześcijaństwo nie było dla niego jedynie jakąś ideą, ale wydarzenie, i wyzwaniem, a zarazem orędziem głoszącym obecność Wcielenia, które się wydarzyło i dalej wydarza dzięki pośrednictwu wolnego i rozumnego człowieka i Kościoła. Dlatego też każda autentyczna formacja chrześcijańska nie może zaniedbywać wychowania do coraz głębszego poznawania i umiłowania Kościoła jako całości, a więc również jego wymiaru instytucjonalnego. Wolność religijną uważał za prawo należne każdemu, a jeśli nie jest respektowana to, jego zdaniem, „trzeba ją wywalczyć, gromadząc się pod właściwym autorytetem”.

Traktując chrześcijaństwo jako wydarzenie proponował wychowanie, które nie kończy się w pewnym wieku, ale trwa nieustannie, ponieważ wciąż się odnawia i pogłębia. Od początku miał też jasną świadomość, że nie jest tutaj, aby wychowywana przez niego młodzież przyjęła, jako swoje idee, które przekazywał, lecz aby nauczyć ją prawdziwej metody osądzania rzeczy, które sam przekazywał. To zaś, co przekazywał, „jest, jak sam mówił, doświadczeniem wynikającym z dwu tysięcy lat". Pracę wychowawczą, będącą sprawą serca (miłości), zasadzał na tym, ażeby nastąpiło przejście od zafascynowania spotkaniem do świadomości tego wszystkiego, co to spotkanie w sobie zawiera. Dlatego uczył, że istnieje różnica między wychowaniem a nauczanie. Jego zdaniem uczyć może robot, wychowanie zaś jest miłowaniem ucznia i dawaniem świadectwa o tym, w jaki sposób wydarzenie chrześcijańskie stanowi najbardziej prawdziwą odpowiedź na wymogi ludzkiego serca. Głosił przy tym potrzebę lojalności wobec człowieczeństwa, które traktował jako największy zasób, jaki człowiekowi został dany. Młodych uczył intensywnego przeżywania rzeczywistości i pomagania sobie nawzajem jak bracia, a charyzmat, jaki propagował, pozwalał młodym i dorosłym wzrastać w przyjaźni z Jezusem i dawać o nim

43 Szerzej na ten temat piszę w artykułach: Wychowanie człowieka $w$ duchu „Zmysłu religijnego" i Wychowanie otwarte na hipotezę Objawienia, w: Wychowanie człowieka otwartego. 
świadectwo. Zwracał przy tym uwagę na świadomość własnych potrzeb i zalecał weryfikować wiarę z codziennym życiem. Dialogując z młodymi, starał się lepiej ich poznać i zrozumieć, szanując ich rytm rozwoju i specyfikę.

Streszczenie: Niniejsza publikacja przybliża wielorako manifestującą się charyzmatyczną działalność pedagogiczną znanego ze swych licznych dokonań włoskiego nauczyciela i wychowawcę, ks. Luigiego Giussaniego. Bez wątpienia człowiek ten ze względu na swą wyjątkową wnikliwość i odwagę był postacią znaną i cenioną nie tylko w życiu uniwersyteckim, kościelnym ale także szkolnym, kulturalnym i politycznym.

Autorka opracowania uwzględniając aspekt pedagogiczny zwraca uwagę na Giussaniego jako wyjątkowego nauczyciela i wychowawcę. Przybliża jego sposób rozumienia pedagogiki i wychowania a prezentując z jego biografii wybrane dokonania, potwierdza jego wyjątkowość. Jako nauczyciel i wychowawca ks. Giussani odznaczał się trzeźwym i realistycznym spojrzeniem na człowieka i jego wychowanie. Podkreślając wartość osoby jako istoty rozumnej i wolnej jego postawa charakteryzowała się całkowitym zawierzeniem Bogu i wielką miłością do każdego spotkanego człowieka.

Publikacja zawiera krótki rys biograficzny, opisuje preferowane przez Giussaniego sposoby wychowania, zdarzenia wychowujące, elementy konstytuujące osobowość wychowującego i wychowywanego jak również ukazuje związek wychowania z wolnością, sumieniem i tradycją.

Słowa kluczowe: ks. Luigi Giussani, rys biograficzny, wychowane, zdarzenia wychowujące, elementy konstytuujące osobowość wychowującego i wychowywanego, związek wychowania z wolnością, sumieniem i tradycją.

\section{Bibliografia}

\section{Źródła}

Giussani L., Allorigine della pretesa cristiana, t. 2, Milano 1988.

Giussani L., Cała ziemia pragnie Twojego oblicza, przeł. D. Chodyniecki, Kielce 2004.

Giussani L., Chrześcijaństwo jako wyzwanie. U źródeł chrześcijańskiego roszczenia, przeł.

D. Chodyniecki, Poznań 2002.

Giussani L., Czas i Świątynia. Bóg i człowiek, przeł. K. Borowczyk, słowo wstępne

F. Macharski, Częstochowa 1997.

Giussani L., Dlaczego Kościót?, przeł. D. Chodyniecki. Poznań 2004.

Giussani L., Doświadczenie jest drogą do prawdy, przeł. D. Chodyniecki, Kielce 2003.

Giussani L., Il senso religioso, t. 2, Milano 1986.

Giussani L., Miejsce chrześcijanina w świecie, przeł. K. Kubis, A. Porębski, Kraków 2003. 
Giussani L., Perchè la Ciesa? La pretesa rimane, t. 3, Milano 1990.

Giussani L., Ryzyko wychowawcze, przeł. D. Chodyniecki, Kielce 2021.

Giussani L, Śladami chrześcijańskiego doświadczenia, przeł. K. Klauza, red. i wstęp do polskiego wydania Z. Bradel. Warszawa 1988.

Giussani L., Alberto S., J. Prades J., Zostawić ślady w historii świata, Opole 2011.

Giussani L., Wydarzenie wolności. Rozmowy ze studentami, przeł. D. Chodyniecki, Opole 2020.

Giussani L., W prostocie mego serca radośnie oddałem Ci wszystko. Świadectwo księdza Giussaniego podczas spotkania z Ojcem Świętym. Plac Św. Piotra, 30 maja 1998, w: Comunione e Liberazione. Ruch w Kościele, red. D. Rondoni, przeł. W. Janusiewicz, Milano 1998, s. 110-112.

Giusani L., Zaangażowanie chrześcijanina w świecie, w: H. Urs von Balthazar, L. Giussani, Miejsce chrześcijanina w świecie, przeł. K. Kubis, A. Porębski, Kraków 2003, S. $115-184$.

Giussani L., Zmysł Boga a człowiek wspótczesny. „Kwestia ludzka” i nowość chrześcijaństwa, przeł. K. Borowczyk, „Ślady”, 1997 nr 5-6 (38-39), s. 12-13.

\section{Opracowania}

Camisasca M., Comunione e Liberazione. Il ricononoscimento (1976-1984). Apendice 19852005, San Paolo 2006.

Camisasca M., Comunione e Liberazione. Le origini (1954-1968), San Paolo 2001.

Campagniaro M., Wiara to fascynujące spotkanie. Przekaz wiary w społeczeństwie zsekularyzowanym na podstawie pism Luigiego Giussaniego, Warszawa 2017.

Comunione e Liberazione. Ruch w Kościele, red. D. Rondoni, przeł.. W. Janusiewicz, Milano 1998.

Flis-Jaszczuk M., Rec. Luigi Giussani, Ryzyko wychowawcze jako tworzenie osobowości i historii, Kielce: Wydawnictwo „Jedność”, 2002, „Roczniki Nauk Społecznych”, 30 (2002) z. 2 s. 236-238.

Jan Paweł II, List Ojca Świętego [...]: Na pogrzeb ks. prałata Luigi Giussaniego, Watykan, 22 lutego 2005.

Messori V., Dwa sposoby na życie wiara. Luigi Giussani, w: Pytania o chrześcijaństwo, Kraków 1997, s. 2007-218;

Rynio A., Fr Luigi Giussani's Concept of Education - an Outline, „The Person and the Challenges", 1 (2011) nr 2, s. 149-165, DoI: 10.15633/pch.858

Rynio A., Ks. Luigi Giussani: „Ja jestem zerem, Bóg jest wszystkim”, „Przegląd Uniwersytecki KUL", 3 (2005), s. 24.

Rynio A., Przykład niezwykłego etosu pedagogicznego (ks. Luigi Giussani, 1922-2005), w: Człowiek u progu trzeciego tysiaclecia. Zagrożenia i wyzwania, t. 2, red., M. Plopa, Elbląg 2007, s. 211-228. 
Rynio A., Wychowanie człowieka w duchu „Zmysłu religijnego”, w: Wychowanie człowieka otwartego. Rola „Zmysłu religijnego” Luigi Giussaniego w kształtowaniu osoby, red. A. Rynio, Kielce 2001, s. 71-84.

Rynio A., Wychowanie otwarte na hipotezę Objawienia, w: Wychowanie człowieka otwartego. Rola „Zmysłu religijnego" Luigi Giussaniego w kształtowaniu osoby, red. A. Rynio, Kielce 2001, s. 88-97.

Rynio A., Wychowawcza metoda ks. L. Giussaniego, w: Wychowanie człowieka otwartego. Rola „Zmysłu religijnego" Luigi Giussaniego w kształtowaniu osoby, red. A. Rynio, Kielce 2001, s. 98-102.

Rynio A.,, Specyfika wychowania do wiary w posłudze założyciela ruchu Comunione e Liberazione - Ks. Luigi Giussaniego, w: Universitati serviens, Księga pamiątkowa ku czci Księdza Profesora Stanisława Wilka SDB, red., ks. J. Walkusz, M. Krupa, Lublin 2014, s. 667-680.

Savorana A., Vita di don Giussani, Milano 2013. 